\title{
PENGARUH PEMBUNGKUS TEMPE TERHADAP DAYA SIMPAN DAN SIFAT FISIK TEMPE
}

\author{
Priyo Sulistiyono $^{1}$, Samuel $^{2}$, Mey Mey Mailani ${ }^{3}$ \\ ${ }^{123}$ Program Studi D III Gizi Cirebon Poltekkes Kemenkes Tasikmalaya
}

\begin{abstract}
ABSTRAK
Tempe adalah salah satu makanan fermentasi tradisional Indonesia yang mengandung nutrisi yang cukup tinggi. Pengemasan berperan penting dalam pengendalian dari kontaminasi mikroorganisme terhadap produk bahan pangan. Penelitian ini mempelajari pengaruh jenis pembungkus plastik, daun pisang dan daun jati terhadap daya simpan dan sifat fisik tempe. Penelitian adalah quasi eksperimen dengan desain Rancangan Acak Lengkap (RAL) terdiri dari tiga perlakuan (jenis pembungkus tempe). Perbedaan daya simpan dan sifat fisik antar perlakuan di uji Kruskal-Wallis dan uji lanjut $L S D$. Hasil penelitian menunjukan jenis pembungkus tempe (plastik, daun pisang dan daun jati) mempengaruhi daya simpan dan sifat fisik tempe. Tempe dengan pembungkus plastik lebih cepat busuk, dibanding dibungkus daun jati dan daun pisang. Tempe dengan pembungkus daun pisang menunjukan persentase sifat fisik tertinggi. Ada pengaruh jenis pembungkus tempe terhadap daya simpan dan sifat fisik tempe.
\end{abstract}

Kata Kunci : Daya Simpan, Pembungkus, Sifat Fisik, Tempe.

\begin{abstract}
Tempe is one of the traditional Indonesian fermented food containing nutrients is quite high. Packaging plays an important role in the control of microorganism contamination of the food product. This research studies the influence of the plastic wrap, banana leaves and leaves of teak on the shelf and physical properties. The study design quasi-experiment with Completely Randomized Design (CRD) consisting of 3 treatment (type of wrapping tempe). Storability and differences between treatments in physical properties Kruskal-Wallis and LSD. Tempe's wrap type (plastic, banana leaves and leaves of teak) affects storability and physical properties of tempe. Tempe with plastic wrapping faster decay, rather than wrapped in teak leaves and banana leaves. Tempe with banana leaf wrappers shows the average best physical properties. There is a kind of wrapper tempe influence on storability and physical properties of tempe.
\end{abstract}

Keywords : Packaging, Power Save, Physical Properties, Tempe.

\section{PENDAHULUAN}

Indonesia merupakan negara produsen tempe terbesar di dunia dan menjadi pasar kedelai terbesar di Asia. Sebanyak 50\% dari konsumsi kedelai Indonesia diperoleh dalam bentuk tempe. Konsumsi tempe rata-rata pertahun di Indonesia saat ini sekitar $6,45 \mathrm{~kg} /$ orang. (Astawan, 2009). Tempe merupakan bahan makanan hasil fermentasi kacang kedelai atau jenis kacang-kacangan lainnya menggunakan jamur Rhizopus oligosporus dan Rhizopus oryzae. Tempe umumnya dibuat secara tradisional di Indonesia pembuatan tempe sudah menjadi industri rakyat (Francis, 2000 dalam Suharyono dan Susilowati, 2006). Tempe mengandung berbagai nutrisi yang diperlukan oleh tubuh seperti protein, lemak, karbohidrat, dan mineral. Beberapa penelitian menunjukkan bahwa zat gizi tempe lebih mudah dicerna, diserap, dan dimanfaatkan tubuh. 
Priyo S., Samuel, Mey M.M., Poltekkes Tasikmalaya.; Daya Simpan, Pembungkus, Sifat Fisik, Tempe.

Pengemasan bahan pangan memegang peranan penting dalam pengendalian dari kontaminasi mikroorganisme terhadap produk bahan pangan. Pangan yang tercemar oleh mikroorganisme dan disimpan dalam kondisi yang memungkinkan aktivitas metabolisme dapat menimbulkan kerusakan bahan pangan dan membahayakan kesehatan konsumen (Supardi dan Sukamto, 1999).

Tempe merupakan produk fermentasi tidak dapat bertahan lama. Daya simpan tempe relatif singkat. Penyimpanan tempe pada umumnya di rumah dan di pasar swalayan dilakukan dalam lemari pendingin. Menurut Setyawati (2008) tempe dengan penyimpanan baik dapat bertahan 5-10 jam. Tempe yang ditumpukan menimbulkan panas sehingga tempe akan lebih cepat membusuk. Tempe dapat bertahan satu hari di udara terbuka tanpa perubahan rasa. Tempe yang disimpan dilemari pendingin akan bertahan 23 hari. Penyimpanan dalam refrigerator hanya bertahan 2-3 hari. Tempe akan mengalami perubahan cita rasa meski belum membusuk. Penyimpanan tempe dalam freezer bisa bertahan lebih dari sebulan (Suprapti, 2003).

Cita rasa tempe ditentukan dari jenis kedelai dan jenis pembungkus tempe saat pemeraman (fementasi). Masyarakat selama

\section{METODE PENELITIAN}

Penelitian daya simpan dan sifat fisik tempe menurut jenis pembungkusnya menggunakan rancangan acak sederhana. Kontrol tempe dengan pembungkus daun pisang (DP) dan sampel perlakuan tempe pembungkus plastik (PL) dan daun jati (DJ). Pengamatan dilakukan 2 (dua) kali ulangan, sehingga didapat 6 satuan percobaan.

Sampel tempe dibuat oleh produsen tempe AGH Kabupaten Sumedang. Bahan kedelai kuning lokal varietas burangrang, ragi merek raprima dengan konsetrasi $0,15 \%$. Tebal pembungkus untuk daun dua lapis. suhu pemeraman (suhu kamar $27^{\circ}-29^{\circ} \mathrm{C}$ ) dan laman pemeraman 24 jam. Sampel tempe dibuat sekaligus untuk ketiga perlakuan, sampel diambil secara random untuk dilakukan uji daya simpan dan uji sifat fisik. Penyimpanan dan pengujian sifat fisik tempe ini mengenal tiga jenis pembungkus tempe, yaitu plastik, daun pisang dan daun jati. Kemasan plastik memiliki kelebihan; kuat, ringan, tidak karatan serta dapat diberi warna, sedangkan kelemahannya; molekul kecil plastik dapat melakukan migrasi ke dalam bahan makanan yang dikemas. Daun pisang memiliki kelebihan pembungkus alami yang tidak mengandung bahan kimia, mudah ditemukan, mudah dilipat dan memberi aroma sedap. Daun pisang sebagai pembungkus memiliki kekurangan; mudah sobek dan kurang bersih. Daun jati memiliki kelebihan tidak mengandung bahan kimia tapi memiliki kekurangan bila tersentuh kulit tangan akan terasa sedikit gatal dan sulit didapat pada musim kemarau (Winarno, 1994).

Bagaimana pengaruh jenis pembungkus tempe (plastik, daun pisang, dan daun jati) terhadap lama penyimpanan (daya simpan) dan sifat fisik (organoleptik). Penelitian ini akan menjawab apakah lama penyimpanan dan sifat fisik tempe, dipengaruhi oleh jenis pembungkusyaitu pembungkus plastik, daun pisang dan daun jati. Penelitian ini diharapkan menghasilkan informasi pembungkus yang baik untuk tempe didasarkan atas daya simpan dan sifat fisik tempe.

kedelai yang dibungkus plastik, daun pisang, dan daun jati dilaksanakan di Laboratorium Teknologi Pangan Progam Studi DIII Gizi Cirebon.

Pengumpulan data sifat fisik tempe dilakukan oleh panelis agak terlatih sebanyak 20 orang mahasiswa Prodi D III Gizi Cirebon semester IV dan VI. Panelis memenuhi syarat panelis yaitu sehat, tidak buta warna, menyukai tempe, tidak dalam keadaan lapar dan menyatakan bersedia menilai. Pengujian sifat fisik tempe secara organoleptik meliputi warna, aroma, rasa, dan tekstur. Penilaian menggunakan skala 1-5, meliputi warna (Tidak putih-sangat putih), Aroma (tidak khas tempe-sangat khas tempe), Tekstur (tidak keras-sangat keras), Rasa (tidak enak-sangat enak). 
Priyo S., Samuel, Mey M.M., Poltekkes Tasikmalaya.; Daya Simpan, Pembungkus, Sifat Fisik, Tempe.

Daya simpan diukur dari mulai pengemasan sampai ditemukan tanda-tanda pembusukan, yaitu bintik kuning/coklat lebih dari 10 bintik, berlendir, aroma berubah dan tekstur tidak keras (tidak lagi kompak). Sampel tempe dilakukan pengamatan mulai 3

\section{HASIL PENELITIAN}

Daya Simpan Tempe. Pengukuran daya simpan tempe menggunakan lamanya waktu tempe dari pemeraman setah peragian, sampai ditemukan tanda-tanda pembusukan. jam pertama, dan setiap 3 jam berikutnya. Analisis Kruskal Wallis untuk melihat perbedaan nilai data sifat fisik dan daya simpan tempe antar perlakuan yaitu pembungkus daun pisang (DP), plastik (PL) dan daun jati (DJ).

Penilaian tanda pembusukan menggunakan beberapa parameter seperti; perubahan warna, aroma dan tekstur yang menunjukan tanda-tanda pembusukan.

Tabel 1. Daya Simpan Tempe menurut Jenis Pembungkus $(n=40)$

\begin{tabular}{lcccccc}
\hline Pembungkus & \multicolumn{6}{c}{ Daya Simpan } \\
\cline { 2 - 6 } & $\begin{array}{c}\text { cepat } \\
\text { busuk }\end{array}$ & $\%$ & $\begin{array}{c}\text { tidak cepat } \\
\text { busuk }\end{array}$ & $\%$ & Jumlah & $\%$ \\
\hline Plastik & 37 & 92.5 & 3 & 7.5 & 40 & 100 \\
\hline Daun Pisang & 4 & 10.0 & 36 & 90.0 & 40 & 100 \\
\hline Daun Jati & 11 & 27.5 & 29 & 72.5 & 40 & 100 \\
\hline$p$-value 0,000 & & & & & &
\end{tabular}

Daya simpan tempe menurut jenis pembungkus (plastik, daun pisang dan daun jati), menunjukan tempe yang cepat busuk adalah tempe dengan pembungkus plastik (92,5\%), disusul daun jati $(27,5 \%)$. Tempe dengan pembungkus daun pisang memiliki daya simpan paling lama.

Uji statistik kruskal wallis digunakan untuk uji beda data kategorik lebih dari dua kelompok data. Hasil uji menunjukkan perbedaan yang bermakna daya simpan tempe menurut jenis pembungkusnya $(p=0,00$ atau <0,05). Uji lanjutan dengan uji $L S D$ menunjukan ada perbedaan daya simpan tempe antara pembungkus tempe plastik dan daun pisang $(p=0,000)$ dan daun pisang $(p=0,000)$ dan tidak ada perbedaan daya simpan daun pisang dan daun jati $(p=0,46)$.

Sifat Fisik Tempe. Uji sifat fisik tempe dilakukan oleh 20 orang mahasiswa prodi D.III Gizi Cirebon semester IV dan VI. Penilaian sifat fisik meliputi warna, aroma, tekstur dan rasa tempe.

Tabel 2. Hasil Uji Sifat Fisik Tempe menurut Jenis Pembungkus $(n=3 \times 50)$

\begin{tabular}{lcccc}
\hline \multirow{2}{*}{ Pembungkus } & \multicolumn{5}{c}{ Sifat Fisik (\% baik) } \\
\cline { 2 - 5 } & Warna & Aroma & Tektur & Rasa \\
\hline Plastik & 90 & 82 & 68 & 68 \\
\hline Daun Jati & 98 & 94 & 58 & 86 \\
\hline Daun Pisang & 100 & 96 & 66 & 82 \\
\hline$p$-value & 0.09 & 0,044 & 0,139 & 0,025 \\
\hline
\end{tabular}

Warna tempe dengan pembungkus daun pisang $100 \%$ memiliki warna yang baik yaitu putih. Warna tempe dengan pembungkus plastik dan daun jati sedikit dibawah daun pisang tapi tergolong baik (putih). Hasil uji Kruskal Wallis menunjukan tidak ada 
Priyo S., Samuel, Mey M.M., Poltekkes Tasikmalaya.; Daya Simpan, Pembungkus, Sifat Fisik, Tempe.

perbedaan bermakna warna tempe antar ketiga perlakuan $(p=0,09)$.

Aroma tempe yang terbaik yaitu aroma khas tempe terdapat pada tempe dengan pembungkus daun pisang. Hasil uji Kruskal Wallis menunjukan perbedaan bermakna $(p=0,044)$. Hasil uji lanjutan $L S D$ menunjukkan aroma tempe pembungkus daun pisang berbeda nyata dengan plastik $(p=0,022)$, namun tidak berbeda dengan daun jati $(0,645)$. Aroma tempe plastik tidak berbeda daun jati $(p=0,055)$. Tekstur tempe dengan pembungkus plastik memiliki tektur paling baik dibandingan tempe pembungkus

\section{PEMBAHASAN}

Institute of Food Science and Technology (1974), mengungkapkan bahwa umur simpan produk pangan adalah selang waktu antara saat produksi hingga konsumsi di mana produk berada dalam kondisi yang memuaskan berdasarkan karakteristik penampakan, rasa, aroma, tekstur, dan nilai gizi. Pada saat baru diproduksi, mutu produk dianggap dalam keadaan $100 \%$ dan akan menurun sejalan dengan lamanya penyimpanan atau distribusi. Pangan selama penyimpanan dan distribusi akan mengalami kehilangan bobot, nilai pangan, mutu, nilai uang, daya tumbuh, dan kepercayaan (Rahayu, 1998).

Tempe yang mulai membusuk ditandai perubahan warna dari warna kapang putih menjadi kuning kecoklatan, ini merupakan hasil oksidasi karena pertumbuhan mikroba pencemar. Tanda pembusukan tempe juga dapat dilihat dari aroma tempe menjadi bau amonia, menurut Kasmidjo (1990) hal ini karena terjadi degradasi protein lanjut sehingga terbentuk amonia.

Tempe yang dibungkus plastik lebih cepat busuk dibandingkan tempe dibungkus daun pisang dan daun jati, hal ini disebabkan karena plastik adalah kemasan yang kedap udara meskipun telah dilubangi sebelum proses pengemasan, karena kapang tempe membutuhkan banyak udara. Tempe yang dibungkus daun mengalami aerasi (sirkulasi udara) yang lebih baik melalui celah-celah pembungkus yang ada. Soekarno (2008) lain. Hasil uji Kruskal-Wallis menunjukan tidak ada perbedaan bermakna tektur dari ketiga jenis pembungkus tempe $(p=0,139)$.

Rasa tempe yang diujikan adalah tempe kondisi matang (digoreng). Rasa tempe yang paling disukai adalah rasa tempe pembungkus daun pisang. Hasil uji KruskalWallis menunjukkan ada perbedaan rasa tempe pada berbagai jenis pembungkus $(p=0.025)$, Uji $L S D$ menunjukan rasa tempe pembungkus plastik berbeda dengan daun pisang $(p=0.013)$, dan daun jati $(p=0.032)$. Rasa tempe daun pisang dan daun jati tidak terdapat perbedaan nyata $(p=0.645)$.

mengungkapkan bahwa pengujian sifat fisik pangan dapat dilakukan dengan pengujian organoleptik. Pengujian organoleptik dilakukan dengan sensasi dari rasa, bau/aroma, dan tekstur pada saat dimakan.

Warna merupakan tanda kemasakan atau kerusakan dari makanan, seperti perlakuan penyimpanan yang memungkinkan adanya perubahan warna. Warna makanan yang sesuai dan menarik dapat digunakan teknik memasak tertentu atau dengan penyimpanan yang baik (Meilgaard, 2000). Warna khas tempe adalah putih. Warna putih ini disebabkan adanya miselia kapang yang tumbuh pada permukaan biji kedelai. Proses pemeraman (fermentasi) tempe dengan berbagai pembungkus akan mempengaruhi warna yang dihasilkan.

Warna dasar tempe adalah kuning karena warna bahan kedelai yang digunakan mempunyai warna kuning (Adisarwanto, 2005). Perbedaan kesan warna kuning juga dapat disebabkan karena penerimaan orang terhadap warna yang berbeda-beda, dimana penerimaan warna dipengaruhi oleh beberapa faktor. Winarno (1994) mengungkapkan penerimaan warna suatu bahan makanan tergantung dari faktor alam, geografis dan aspek sosial masyarakat penerima.

Aroma adalah rasa dan bau yang sangat subyektif serta sulit diukur, karena setiap orang mempunyai sensitifitas dan kesukaan yang berbeda. Seseorang dapat mendeteksi, 
Priyo S., Samuel, Mey M.M., Poltekkes Tasikmalaya.; Daya Simpan, Pembungkus, Sifat Fisik, Tempe.

tetapi setiap individu memiliki kesukaan yang berlainan (Meilgaard, 2000). Aroma tempe terbaik yaitu aroma khas tempe dengan pembungkus daun pisang. Aroma langu masih tercium namun sudah berkurang. Menurut Sediaoetama (1993) aroma langu khas kedelai disebabkan enzim lipsigenase yang terkandung dalam kedelai Aroma langu tersebut menjadi berkurang karena kedelai difermentasi menjadi tempe.

Tekstur tempe dengan pembungkus plastik memiliki tektur paling baik dibandingan tempe pembungkus lain, meskipun secara statistik tidak menunjukkan ada perbedaan bermakna tektur dari ketiga jenis pembungkus tempe. Tekstur tempe disebabkan oleh miselia - miselia kapang yang menghubungkan antara biji - biji kedelai. Tekstur tempe dapat diketahui dengan melihat lebat tidaknya miselia yang tumbuh pada permukaan tempe. Miseliayang lebat menunjukkan bahwa tekstur tempe telah membentuk masa yang kompak.

Rasa merupakan tanggapan atas adanya rangsangan kimiawi yang sampai di indera pengecap lidah, khususnya jenis rasa

\section{KESIMPULAN}

Tempe dengan daya simpan terbaik adalah tempe dengan pembungkus daun pisang, dengan urutan daun pisang, daun jati dan plastik. Sifat fisik keseluruhan tempe, terbaik adalah tempe dengan pembungkus

\section{REFERENSI}

Astawan M., (2004). Tetap sehat dengan produk makanan olahan. Solo: Tiga Serangkai.

Astawan, M.M.S., ( 2009). Sehat dengan hidangan kacang dan biji-bijian. Depok: Penebar Swadaya.

Kasmidjo, R.B., (1990). Tempe: mikrobiologi dan kimia pengolahan serta pemanfaatannya. PAU Pangan dan Gizi UGM. Yogyakarta. Dikutip dari KTI: Nurita Puji Astuti, 2009. Sifat organoleptik tempe kedelai yang dibungkus plastik, daun pisang dan daun dasar yaitu manis, asin, asam, dan pahit (Meilgaard, 2000). Pada konsumsi tinggi indera pengecap akan mudah mengenal rasa-rasa dasar tersebut. Beberapa komponen yang berperan dalam pemantauan rasa makanan adalah aroma makanan, bumbu masakan dan bahan makanan, keempukan atau kekenyalan makanan, kerenyahan makanan, tingkat kematangan dan temperaturmakanan (Meilgaard, 2000).

Instrumen yang paling berperan mengetahui rasa suatu bahan pangan adalah indera lidah. Pengawasan mutu makanan, rasa termasuk komponen yang sangat penting untuk menentukan penerimaan konsumen. Rasa dapat dijadikan standar dalam penilaian mutu, disisi lain rasa adalah sesuatu yang nilainya sangat relatif (Winarno, 1993). Rasa tempe yang diujikan adalah tempe dalam kondisi matang (digoreng). Rasa tempe yang paling disukai adalah rasa tempe dengan pembungkus daun pisang. Setiap panelis pasti berbeda-beda menilai rasa karena menurut Winarno (1997) rasa adalah sesuatu yang nilainya sangat relatif.

daun pisang, terutama untuk warna dan aroma. Tempe tekstur terbaik (padat/keras) adalah tempe dengan pembungkus plastik. Tempe dengan rasa terbaik adalah tempe dengan pembungkus daun jati.

jati. Universitas Muhammadiyah

Surakarta.

Meilgaard, (2000). Sensory Evaluation

Techniques. CRC. Boston. Dikutip dari:

Ratmawati, Devi. 2012. Substitusi

tepung tempe pada pembuatan kue bolu kukus terhadap kadar protein, tingkat pengembangan dan daya terima. Skripsi, Universitas muhammadiyah Surakarta.

Rahayu, W.P., (1998). Penuntun praktikum penelitian organoleptik. Bogor: Jurusan Teknologi Pangan dan Gizi Fakultas teknologi Pertanian IPB. 
Priyo S., Samuel, Mey M.M., Poltekkes Tasikmalaya.; Daya Simpan, Pembungkus, Sifat Fisik, Tempe.

Setyawati, D., (2008). 100 menu masakan tahu tempe. Yogyakarta: Gradien Mediatama.

Suharyono, A. dan Susilawati, (2006). Pengaruh jenis tempe dan bahan pengikat terhadap sifat kimia dan organoleptik produk nugget tempe. Prosiding seminar hasil-hasil penelitian dan pengabdian kepada masyarakat 2006.

Suprapti, L., (2003). Pembuatan tempe.

Yogyakarta: kaninus.

Supardi dan Sukamto, (1999). Mikrobiologi, pengolahan dan keamanan pangan. Jakarta: Alumni.

Winarno, (1997). Sterilisasi komersial produkproduk pangan. Jakarta: Gramedia. 